\title{
Productive Potential of Nitrogen and Zinc Fertigated Sugarcane
}

\author{
Fernando Nobre Cunha ${ }^{1, *}$, Marconi Batista Teixeira ${ }^{1}$, Edson Cabral da Silva ${ }^{1} \mathbb{1}$, \\ Nelmício Furtado da Silva ${ }^{1}$, Cicero Teixeira Silva Costa ${ }^{2}$, Vitor Marques Vidal ${ }^{1}$, \\ Wilker Alves Morais ${ }^{1}$, Leonardo Nazário Silva dos Santos ${ }^{1}$, Fernando Rodrigues Cabral Filho ${ }^{1}(1)$, \\ Daniely Karen Matias Alves ${ }^{1}$, Jaqueline Aparecida Batista Soares ${ }^{1}$ and Luiz Fernando Gomes ${ }^{1}$ \\ 1 Hydraulics and Irrigation Laboratory, Federal Institute of Education, Science and Technology \\ Goiano (IFGoiano)-Campus Rio Verde, Rodovia Sul Goiana, Km 01, Zona Rural, \\ Rio Verde-GO 75909-120, Brazil; marconibt@gmail.com (M.B.T.); edsoncabralsilva@gmail.com (E.C.d.S.); \\ nelmiciofurtado@gmail.com (N.F.d.S.); vmarquesvidal@gmail.com (V.M.V.); \\ wilker.alves.morais@gmail.com (W.A.M.); leonardo.santos@ifgoiano.edu.br (L.N.S.d.S.); \\ fernandorcfilho10@gmail.com (F.R.C.F.); daniely_karen@hotmail.com (D.K.M.A.); \\ jaquelineab.soares@gmail.com (J.A.B.S.); luizfernandoz4@hotmail.com (L.F.G.) \\ 2 Irrigation Laboratory, Federal Institute of Education, Science, and Technology of Mato Grosso do \\ Sul, (IFMS)-Campus Naviraí, R. Hilda, 203-Conj. Hab. Boa Vista, Naviraí-MS 79950-000, Brazil; \\ ctsc2007@hotmail.com \\ * Correspondence: fernandonobrecunha@hotmail.com; Tel.: +55-(64)-3620-5600
}

Received: 7 June 2020; Accepted: 23 July 2020; Published: 29 July 2020

\begin{abstract}
The relevance of sugarcane (Saccharum officinarum L.) in the agribusiness is irrefutable because it not only contributes greatly to the development of countries but is also an important source of job creation and income generation. The objective of this study was to evaluate the stalk productivity (SP) and sugar and alcohol yields of plant and ratoon crops of sugarcane (variety IACSP 95-5000) under $\mathrm{N}$ and $\mathrm{Zn}$ fertigation treatments using a central pivot, in Cerrado Red Latosol soil. The experiment was conducted under field conditions, in the municipality of Jataí, Goiás (GO), Brazil. A randomized block design was used, with a $4 \times 5$ split-plot arrangement and three replications. The fertilization treatments consisted of four doses of $\mathrm{N}\left(0,60,120\right.$, and $\left.180 \mathrm{~kg} \mathrm{ha}^{-1}\right)$ and five doses of $\mathrm{Zn}\left(0,2.5,5.0,7.5\right.$, and $\left.10.0 \mathrm{~kg} \mathrm{ha}^{-1}\right)$ in plant and ratoon crops. $\mathrm{N}$ fertilization treatments, in the form of urea, were divided into three applications from 60 days after planting. Zn fertilization, in the form of $\mathrm{Zn}$ sulfate, was applied in a single application. Sugarcane was harvested 330 days after planting. The productivity (SP) was determined by weighing the stalks present in the respective subplots. Sugar and alcohol yields were calculated from the amount of raw sugar determined in the technological analysis. The sugar and alcohol yields of sugarcane (variety IACSP 95-5000) were improved with the fertigation of $180 \mathrm{~kg} \mathrm{ha}^{-1}$ of $\mathrm{N}$, in relation to $\mathrm{Zn}$ doses. Compared with the control (without $\mathrm{N}$ fertigation), sugarcane productivity (plant and ratoon crops) increased by $38.90 \%$ and $13.70 \%$ when treated with $180 \mathrm{~kg} \mathrm{ha}^{-1}$ of $\mathrm{N}$ at the Zn dose of $10 \mathrm{~kg} \mathrm{ha}^{-1}$. Sugarcane (variety IACSP 95-5000) has productive performance, sugar and alcohol yield, optimized and maximized when fertigated with $10 \mathrm{~kg} \mathrm{ha}^{-1}$ of zinc and $180 \mathrm{~kg} \mathrm{ha}^{-1}$ of nitrogen.
\end{abstract}

Keywords: Saccharum spp.; alcohol yield; Oxisol; cerrado

\section{Introduction}

The relevance of sugarcane in the Brazilian agribusiness is irrefutable because it not only contributes greatly to the development of the country but is also an important source of job creation and income generation. Despite investments in the dissemination of technologies to improve the quality of the 
final product, additional scientific research may still contribute greatly to the maximization of the production process [1,2].

Such technologies include the use of irrigation to mitigate the effect of water scarcity, and the use of fertigation to increase the efficient use of nutrients in sugarcane production. Despite these technologies being interesting and viable alternatives, they are still rarely used in sugarcane producing countries. Irrigation promotes economic, social, and environmental sustainability, and is also an important tool to increase sugarcane productivity [3-7]. The use of fertilizers via irrigation (fertigation) reduces losses without increasing production costs, moreover, irrigation alone greatly affects the stalk, sugar, and alcohol yield variables, but fertigation usually intensifies these increases [8-11], and has thus become a relevant technique to supply the water and nutrients required by sugarcane. Due to the importance of this technique, a further understanding of the characteristics related to water and nutrient supply may contribute to significant improvements of sugarcane management systems to obtain higher yields [12].

Nitrogen $(\mathrm{N})$ and zinc $(\mathrm{Zn})$ have been shown to have varied effects on sugarcane (cane-plant), and significant increases in productivity and yield may or may not be associated with the use of these nutrients. Although this ambiguity and the importance of these nutrients are recognized, studies on the association of $\mathrm{N}$ and $\mathrm{Zn}$, mainly administered via irrigation water (fertigation), remain limited [13-16].

Therefore, the objective of this study was to evaluate the stalk productivity (SP) and sugar and alcohol yields of plant and ratoon crops of sugarcane (variety IACSP 95-5000) under N and Zn fertigation treatments using a central pivot, in Cerrado Red Latosol soil.

\section{Material and Methods}

The sugarcane (Saccharum officinarum L) experiment was conducted under field conditions at an average altitude of $907 \mathrm{~m}$ in an area of the Raízen Mill, in the municipality of Jataí, Goiás (GO), Brazil $\left(17^{\circ} 44^{\prime} 2.62^{\prime} \mathrm{S}\right.$ and $\left.51^{\circ} 39^{\prime} 6.06^{\prime} \mathrm{W}\right)$. The area is characterized, which is irregularly distributed throughout the year, by an annual rainfall of $\sim 1800 \mathrm{~mm}$, with rain from October to April and little to no rain from May to September. According to the classification described by Köppen [17], the local climate is tropical savannah with a dry winter (Aw). The minimum and maximum temperatures range from 12 to $15^{\circ} \mathrm{C}$ and 35 to $37^{\circ} \mathrm{C}$, respectively. The average temperature during the experiment was 23.50 and $23.20^{\circ} \mathrm{C}$, average relative humidity was 66.35 and $65.50 \%$, and average rainfall was 115.60 and $103.10 \mathrm{~mm}$, in plant and ratoon crops, respectively (Figure 1).

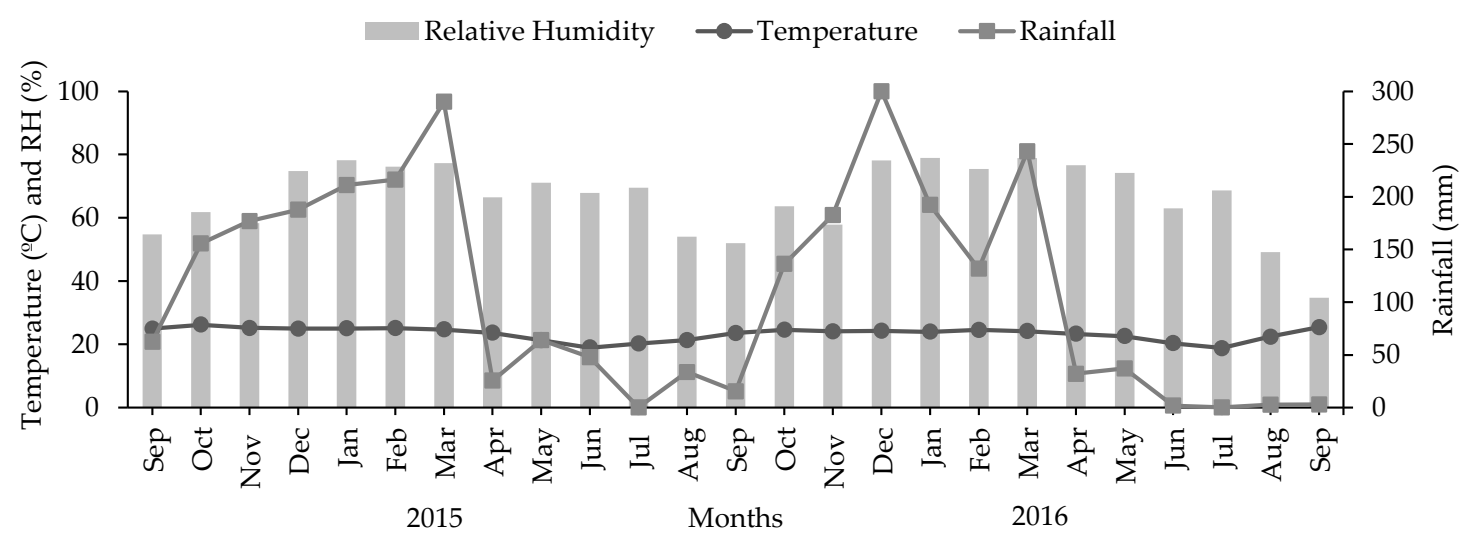

Figure 1. Monthly data on temperature, rainfall, and relative humidity $(\mathrm{RH})$ throughout the experimental period in Jataí-GO, 2015/16. Source: INMET Normal Station-Jataí-GO.

The soil in the experimental area is classified as dystrophic Red Latosol, is very clayey, and in the Cerrado phase [18]. The characteristics and classifications of the soils in the experimental area are described in Table 1. 
Table 1. Physical, chemical, and hydrographic characteristics, and the textural and granulometry classifications of the soil in the experimental area, Jataí-GO.

\begin{tabular}{|c|c|c|c|c|c|c|c|c|c|c|c|}
\hline $\begin{array}{c}\text { Layer }^{1} \\
\text { m }\end{array}$ & $\begin{array}{c}\mathrm{pH} \\
\mathrm{CaCl}_{2}\end{array}$ & $\begin{array}{r}\text { OM } \\
\mathrm{g} \mathrm{dm}^{-}\end{array}$ & $\begin{array}{l}\mathrm{P} \\
\mathrm{mg}\end{array}$ & $\mathrm{mg} \mathrm{dm}^{-3}$ & \multicolumn{6}{|c|}{$\mathrm{mmol}_{\mathrm{c}} \mathrm{dm}^{-3}$} & $\begin{array}{l}\mathrm{V} \\
\%\end{array}$ \\
\hline $0.0-0.1$ & 5.4 & 81 & 33 & 4.0 & 4.8 & 5.4 & 81 & 33 & 4.0 & 4.8 & 5.4 \\
\hline $0.1-0.2$ & 5.6 & 75 & 12 & 7.0 & 4.7 & 5.6 & 75 & 12 & 7.0 & 4.7 & 5.6 \\
\hline $0.2-0.4$ & 5.7 & 74 & 16 & 12.0 & 4.8 & 5.7 & 74 & 16 & 12.0 & 4.8 & 5.7 \\
\hline $\begin{array}{c}\text { Layer } \\
\text { m }\end{array}$ & & \multicolumn{2}{|c|}{ B } & \multicolumn{2}{|c|}{$\mathrm{Cu}$} & \multicolumn{2}{|c|}{$\mathbf{F e}$} & \multicolumn{2}{|c|}{ Mn } & \multicolumn{2}{|c|}{ Zn } \\
\hline $0.0-0.1$ & & \multicolumn{2}{|c|}{0.22} & \multicolumn{2}{|c|}{1.2} & \multicolumn{2}{|c|}{73} & \multicolumn{2}{|c|}{3.9} & \multicolumn{2}{|c|}{1.0} \\
\hline $0.1-0.2$ & & \multicolumn{2}{|c|}{0.16} & \multicolumn{2}{|c|}{1.0} & \multicolumn{2}{|c|}{46} & \multicolumn{2}{|c|}{1.8} & \multicolumn{2}{|c|}{1.2} \\
\hline $0.2-0.4$ & & \multicolumn{2}{|c|}{0.20} & \multicolumn{2}{|c|}{1.1} & \multicolumn{2}{|c|}{55} & & & \multicolumn{2}{|c|}{0.2} \\
\hline Layer & \multicolumn{3}{|c|}{ Granulometry $\left(\mathrm{g} \mathrm{kg}^{-1}\right)$} & \multicolumn{2}{|c|}{ FC } & \multicolumn{2}{|c|}{ PWP } & \multirow{2}{*}{\multicolumn{4}{|c|}{ Textural Classification }} \\
\hline $\mathbf{m}$ & Sand & Silt & Clay & & & & & & & & \\
\hline $0.0-0.1$ & 96 & 82 & 822 & \multirow{2}{*}{\multicolumn{2}{|c|}{46.3}} & \multirow{2}{*}{\multicolumn{2}{|c|}{22.6}} & \multirow{2}{*}{\multicolumn{4}{|c|}{$\begin{array}{l}\text { Very clayey } \\
\text { Very clayey }\end{array}$}} \\
\hline $0.1-0.2$ & 97 & 82 & 822 & & & & & & & & \\
\hline $0.2-0.4$ & 85 & 71 & 845 & \multicolumn{2}{|c|}{45.8} & \multicolumn{2}{|c|}{22.6} & \multicolumn{4}{|c|}{ Very clayey } \\
\hline
\end{tabular}

\footnotetext{
${ }^{1}$ For soil determinations, soil samples with undeformed structure were collected in Uhland rings of $6.34 \mathrm{~cm}$ in diameter and $5 \mathrm{~cm}$ in height. FC: Field capacity; PWP: permanent wilting point; $\mathrm{P}, \mathrm{K}, \mathrm{Ca}$, and $\mathrm{Mg}$ : Resin; $\mathrm{S}$ : Calcium phosphate $0.01 \mathrm{~mol} \mathrm{~L}^{-1}$; $\mathrm{Al}$ : $\mathrm{KCl} 1 \mathrm{~mol} \mathrm{~L} \mathrm{~L}{ }^{-1}$; $\mathrm{H}+\mathrm{Al}$ : SMP; B: hot water; $\mathrm{Cu}, \mathrm{Fe}, \mathrm{Mn}$, and Zn: DTPA; OM: Organic matter; $\mathrm{pH}$ : in $\mathrm{CaCl}_{2}$; $\mathrm{CEC}$ : Cation exchange capacity; V: Saturation of CEC by bases.
}

A randomized block design was used, with a $4 \times 5$ split-plot arrangement and three replications. The fertilization treatments consisted of four doses of $\mathrm{N}\left(0,60,120\right.$, and $\left.180 \mathrm{~kg} \mathrm{ha}^{-1}\right)$ and five doses of $\mathrm{Zn}\left(0,2.5,5.0,7.5\right.$, and $\left.10.0 \mathrm{~kg} \mathrm{ha}^{-1}\right)$ in plant and ratoon crops. The size of the experimental plot was of 0.2 ha. The fertilization treatments were established considering the indication of $60 \mathrm{~kg} \mathrm{ha}^{-1}$ of $\mathrm{N}$ and $5 \mathrm{~kg} \mathrm{ha}^{-1}$ of $\mathrm{Zn}$ [19]. $\mathrm{N}$ fertilization treatments, in the form of urea, were divided into three applications from 60 days after planting (applied in phenophase of tillering). $\mathrm{Zn}$ fertilization, in the form of $\mathrm{Zn}$ sulfate, was applied in a single application (applied after planting). The urea and $\mathrm{Zn}$ sulfate applied by pivot. All treatments were fertilized in the furrow with $\mathrm{P}_{2} \mathrm{O}_{5}\left(100 \mathrm{~kg} \mathrm{ha}^{-1}\right)$ in the form of triple superphosphate, $\mathrm{K}_{2} \mathrm{O}\left(80 \mathrm{~kg} \mathrm{ha}^{-1}\right)$ in the form of potassium chloride, and micronutrients, except $\mathrm{Zn}$, according to soil analysis results and recommendations by Sousa and Lobato [19].

The variety used in the experiment was IACSP95-5000, under plant cane conditions. This variety is mainly characterized by a high agricultural production, upright position, excellent ratoon sprouting, high sucrose content, resistance to the major diseases, favorable tillering and canopy closure in medium environments, and does not flower or exhibit tumbling [20].

Soil was prepared using the conventional system, through ploughing and harrowing, followed by the opening of the planting furrows. Planting was mechanized, carried out commercially, and following the recommended number of buds per meter for the specific variety used.

Irrigation was performed by a central pivot, model PC 08-64/03-647/01-646/L4 + AC, made of galvanized steel, under low pressure, with 12 support towers. Irrigation was applied over a total area of 139.31 ha at a speed of $268 \mathrm{~m} \mathrm{~h}^{-1}$ in the last tower, applying a minimum gross blade of $1.35 \mathrm{~mm}$ (for one turn to $100 \%$ ). The irrigation was managed using the IRRIGER ${ }^{\circledR}$ software.

Sugarcane degree $\left({ }^{\circ}\right)$ Brix was monitored in the field in the four weeks prior to harvesting. The maturation index (MI) was determined using a portable refractometer to establish the sugarcane time of harvesting, MI classified according to Rosseto [21].

Sugarcane was harvested 330 days after planting. The stalk production (SP) was determined by weighing the stalks present in the respective subplots, quantifying the stalk weight within $2 \mathrm{~m}$ of the two central lines. For this, the stalks were cut as close as possible to the soil. The stalks were then spread out and the pointers were detached. The stalks were weighed on a hook-type digital scale (Soil Control) with an accuracy of $0.02 \mathrm{~kg}$ and a capacity of $50 \mathrm{~kg}$. 
A total of 10 stalks were randomly sampled from each plot at harvest and sent to the laboratory of agro-industrial processes of the Raízen Plant, in Jataí, GO, for determination of sugar and alcohol yields, using to the CONSECANA system [22].

Sugar and alcohol yields were calculated from the amount of raw sugar determined in the technological analysis, following [23], using Equations (1) and (2), respectively:

$$
\mathrm{RAç}=\frac{\mathrm{PCC} \times \mathrm{SP}}{100}
$$

where RAç indicates the sugar yield $\left(\mathrm{kg} \mathrm{ha}^{-1}\right)$; PCC indicates the amount of raw sugar (\%) contained in the stalks as determined by the laboratory; SP indicates the stalk production $\left(\mathrm{t} \mathrm{ha}^{-1}\right)$.

$$
\mathrm{RA}=((\mathrm{PCC} \times \mathrm{F})+\mathrm{ARL}) \times \mathrm{Fg} \times 10 \times \mathrm{SP},
$$

where RA indicates the alcohol yield $\left(\mathrm{m}^{3} \mathrm{ha}^{-1}\right)$; PCC indicates the amount of raw sugar (\%) contained in the stalks as determined by the laboratory; F indicates the stoichiometric transformation factor of sucrose into one molecule of glucose and one molecule of fructose, equal to 1.052; ARL indicates the free reducing sugars (\%), whose values vary from $0.70 \%$ to $0.85 \%$, (the distillery uses 0.7 for high PCC values); Fg indicates the Gay Lussac factor, equal to 0.6475; SP indicates the stalk production $\left(\mathrm{t} \mathrm{ha}^{-1}\right)$.

The data were subjected to analysis of variance and the F test $(p<0.05)$. Significant findings were subjected to a regression analysis of the $\mathrm{N}$ and $\mathrm{Zn}$ fertilization levels using the SISVAR ${ }^{\circledR}$ statistical software [24].

\section{Results and Discussion}

The productivity (SP) of plant crops in response to the $\mathrm{N}$ doses was adjusted using the linear model, with $R^{2}>92.90 \%$ (Figure 2A). Compared with the control $\left(0 \mathrm{~kg} \mathrm{ha}^{-1}\right.$ of N), the SP increased by $10.30 \%$, $13.90 \%, 15.10 \%, 13.80 \%$, and $12.90 \%$ when treated with $60 \mathrm{~kg} \mathrm{ha}^{-1} \mathrm{of} \mathrm{N}$ and increased by $30.90 \%, 41.80 \%$, $45.20 \%, 41.30 \%$, and $38.90 \%$ when treated with $180 \mathrm{~kg} \mathrm{ha}^{-1}$ of $\mathrm{N}$, at the $\mathrm{Zn}$ doses of 0, 2.5, 5.0, 7.5, and $10.0 \mathrm{~kg} \mathrm{ha}^{-1}$, respectively. The SP also increased by $0.20,0.32,0.36,0.35$, and $0.35 \mathrm{t} \mathrm{ha}^{-1}$ for each $1 \mathrm{~kg} \mathrm{ha}^{-1}$ increase in $\mathrm{N}$ at the Zn doses of $0,2.5,5.0,7.5$, and $10.0 \mathrm{~kg} \mathrm{ha}^{-1}$, respectively (Figure 2A).

(A)

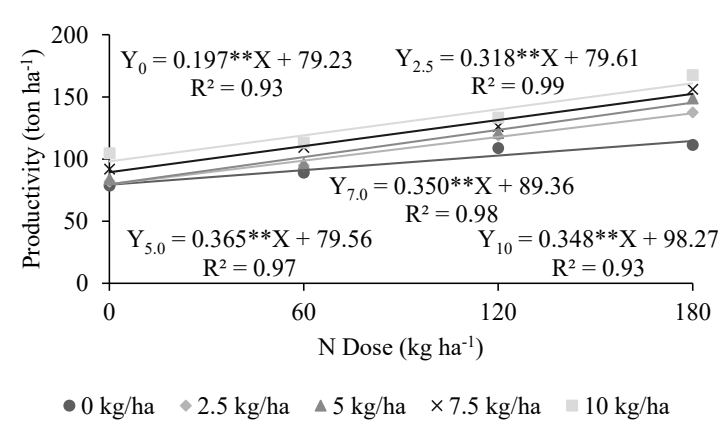

(B)

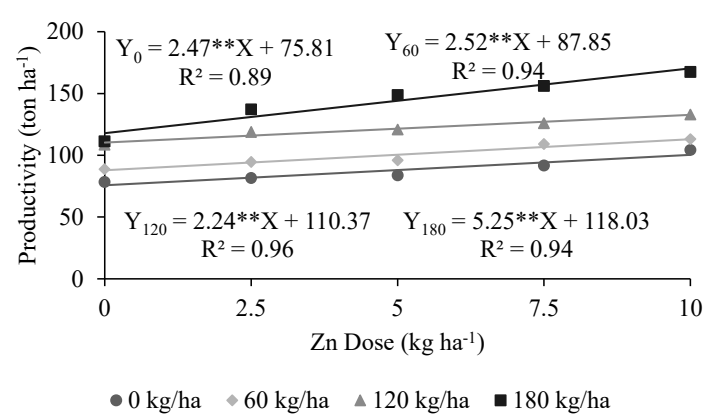

Figure 2. Sugarcane productivity (plant crops) in response to nitrogen (A) and zinc (B) fertigation doses, under field conditions in Jataí, GO, Brazil. ** significant at $p<0,01$ probability according to the $\mathrm{F}$ test. Doses of $\mathrm{Zn}, \mathrm{Y}_{0}: 0 \mathrm{~kg} \mathrm{ha}^{-1}$ of $\mathrm{Zn}, \mathrm{Y}_{2.5}: 2.5 \mathrm{~kg} \mathrm{ha}^{-1}$ of $\mathrm{Zn}, \mathrm{Y}_{5.0}: 5.0 \mathrm{~kg} \mathrm{ha}^{-1}$ of $\mathrm{Zn}, \mathrm{Y}_{7.5}$ : $7.5 \mathrm{~kg} \mathrm{ha}^{-1}$ of $Z \mathrm{n}$ and $\mathrm{Y}_{10}: 10 \mathrm{~kg} \mathrm{ha}^{-1}$ of $\mathrm{Zn}(\mathbf{A})$. Doses of $\mathrm{N}, \mathrm{Y}_{0}: 0 \mathrm{~kg} \mathrm{ha}^{-1}$ of $\mathrm{N}_{,} \mathrm{Y}_{60}: 60 \mathrm{~kg} \mathrm{ha}^{-1}$ of N, $\mathrm{Y}_{120}: 120 \mathrm{~kg} \mathrm{ha}^{-1}$ of $\mathrm{N}, \mathrm{Y}_{180}: 180 \mathrm{~kg} \mathrm{ha}^{-1}$ of $\mathrm{N}($ B).

Teodoro et al. [25] reported that the marginal substitution rate of irrigation water for $\mathrm{N}$ is not fixed, and increases as the irrigation depth decreases, but only to a certain level. These authors also reported that the response of sugarcane to $\mathrm{N}$ fertilization, based on the straight line that limits the production region, increases in direct relation to the water availability of the soil. 
Joris [26] observed that the absorption of $\mathrm{N}$ from fertilizer is lower in medium textured soil than in clayey soil when applied in similar quantities and times; thus concluding that high doses of $\mathrm{N}$ (above $120 \mathrm{~kg} \mathrm{ha}^{-1}$ ) can increase sugarcane SP in responsive environments. In the present study, $\mathrm{N}$ significantly increased the SP and sucrose content of sugarcane (plant crops), thus consequently increasing the sugar yield, under the Zn applications. In addition, a relationship exists between productivity and evapotranspiration in sugarcane, therefore, sugarcane growth and development are directly proportional to the transpired water $[27,28]$. These findings indicate that $\mathrm{N}$ and $\mathrm{Zn}$ fertigation can significantly improve sugarcane SP.

The SP of plant crops in response to the $\mathrm{Zn}$ doses was adjusted using the linear model, with $R^{2}>88 \%$ (Figure 2B). Compared with the control ( $0 \mathrm{~kg} \mathrm{ha}^{-1}$ of $\mathrm{Zn}$ ), the SP increased by $6.10 \%, 5.60 \%, 4.20 \%$, and $7.70 \%$ when treated with $2.5 \mathrm{~kg} \mathrm{ha}^{-1}$ of $\mathrm{Zn}$ and increased by $24.60 \%, 22.30 \%, 16.90 \%$, and $30.80 \%$ when treated with $10 \mathrm{~kg} \mathrm{ha}^{-1}$ of $\mathrm{Zn}$ at $\mathrm{N}$ doses of $0,60,120$, and $180 \mathrm{~kg} \mathrm{ha}^{-1}$, respectively. Sugarcane SP also increased by 2.47, 2.52, 2.24, and $5.25 \mathrm{t} \mathrm{ha}^{-1}$ for each $1 \mathrm{~kg} \mathrm{ha}^{-1}$ increase in $\mathrm{Zn}$ at $\mathrm{N}$ doses of 0,60 , 120 , and $180 \mathrm{~kg} \mathrm{ha}^{-1}$, respectively (Figure 2B).

The application of nutrients via irrigation water promoted a significant increase in sugarcane productivity (>22\%). In addition to a productivity of $152 \mathrm{t} \mathrm{ha}^{-1}$, sugarcane extracts $1.4 \mathrm{~kg} \mathrm{ha}^{-1} \mathrm{of} \mathrm{Mn}$ and $2.3 \mathrm{~kg} \mathrm{ha}^{-1}$ of $\mathrm{Zn}[29,30]$. This SP is similar to the results obtained in the present study in the fertigation treatment with $7.5 \mathrm{~kg} \mathrm{ha}^{-1}$ of $\mathrm{Zn}$ and $180 \mathrm{~kg} \mathrm{ha}^{-1} \mathrm{of} \mathrm{N}$, and is lower than the fertigation treatment with $10.0 \mathrm{~kg} \mathrm{ha}^{-1}$ of $\mathrm{Zn}$ and $180 \mathrm{~kg} \mathrm{ha}^{-1}$ of $\mathrm{N}$ (Figure $2 \mathrm{~B}$ ).

An increased nutrient supply ( $\mathrm{N}$ and $\mathrm{Zn}$ ) has been shown to result in vigorous sugarcane growth [31], consequently resulting in sugarcane plants with maximum height and diameters, and improved total recoverable sugar (TRS) and sugarcane SP. In the present study, the productivity of sugarcane fertigated with the highest doses of $\mathrm{N}$ and $\mathrm{Zn}$ was $>160 \mathrm{tha} \mathrm{h}^{-1}$. Becari [32] reported that $\mathrm{Zn}$ application resulted in a sugarcane SP of $157 \mathrm{t} \mathrm{ha}^{-1}$, which was $21.7 \%$ higher than the productivity (of variety SP 81-3 250) obtained in the controls planted in Red Latosol with low Zn content.

The SP of ratoon crops in response to the $\mathrm{N}$ doses was adjusted using the linear model, with $R^{2}>82 \%$ (Figure 3A). Compared with the control $\left(0 \mathrm{~kg} \mathrm{ha}^{-1}\right.$ of $\left.\mathrm{N}\right)$, the SP increased by $8.70 \%, 6.60 \%, 6.90 \%$, $6.10 \%$, and $4.60 \%$ when treated with $60 \mathrm{~kg} \mathrm{ha}^{-1}$ of $\mathrm{N}$ and increased by $26.20 \%, 19.80 \%, 20.60 \%, 18.30 \%$, and $13.70 \%$ when treated with $180 \mathrm{~kg} \mathrm{ha}^{-1}$ of $\mathrm{N}$, at the $\mathrm{Zn}$ doses of $0,2.5,5.0,7.5$, and $10.0 \mathrm{~kg} \mathrm{ha}^{-1}$, respectively. Sugarcane SP also increased by $0.14,0.12,0.14,0.13$, and $0.11 \mathrm{tha}^{-1}$ for each $1 \mathrm{~kg} \mathrm{ha}^{-1}$ increase in $\mathrm{N}$ at the $\mathrm{Zn}$ doses of $0,2.5,5.0,7.5$, and $10.0 \mathrm{~kg} \mathrm{ha}^{-1}$, respectively (Figure $3 \mathrm{~A}$ ).

(A)

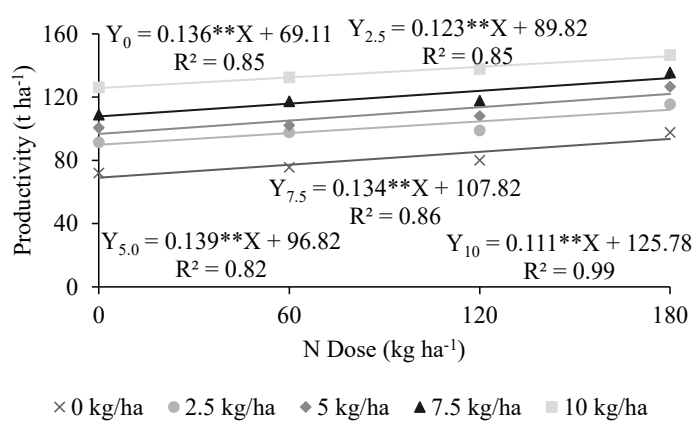

(B)

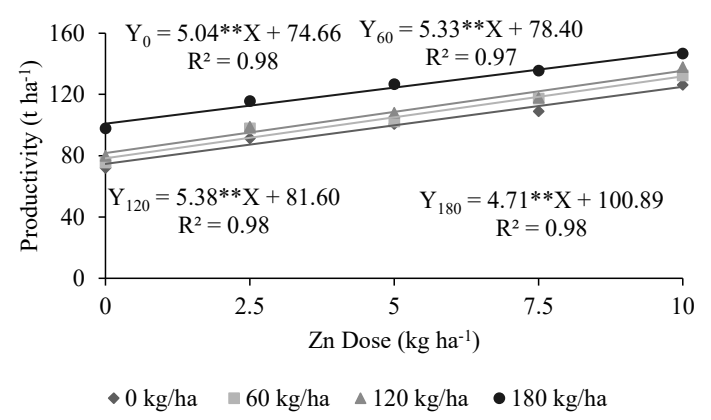

Figure 3. Sugarcane productivity (ratoon crops) in response to nitrogen (A) and zinc (B) fertigation doses under field conditions in Jataí, GO, Brazil. ** significant at $p<0,01$ probability according to the $\mathrm{F}$ test. Doses of $\mathrm{Zn}, \mathrm{Y}_{0}: 0 \mathrm{~kg} \mathrm{ha}^{-1}$ of $\mathrm{Zn}, \mathrm{Y}_{2.5}: 2.5 \mathrm{~kg} \mathrm{ha}^{-1}$ of $\mathrm{Zn}, \mathrm{Y}_{5.0}: 5.0 \mathrm{~kg} \mathrm{ha}^{-1}$ of $\mathrm{Zn}, \mathrm{Y}_{7.5}$ : $7.5 \mathrm{~kg} \mathrm{ha}^{-1}$ of $Z \mathrm{n}$ and $\mathrm{Y}_{10}: 10 \mathrm{~kg} \mathrm{ha}^{-1}$ of $\mathrm{Zn}(\mathbf{A})$. Doses of N, $\mathrm{Y}_{0}: 0 \mathrm{~kg} \mathrm{ha}^{-1}$ of N, $\mathrm{Y}_{60}: 60 \mathrm{~kg} \mathrm{ha}^{-1}$ of N, $\mathrm{Y}_{120}: 120 \mathrm{~kg} \mathrm{ha}^{-1}$ of $\mathrm{N}, \mathrm{Y}_{180}: 180 \mathrm{~kg} \mathrm{ha}^{-1}$ of N (B).

Orlando Filho et al. [33] evaluated the cumulative effect of increasing doses of $\mathrm{N}$ fertilization on the productivity of plant cane and three consecutive ratoon cycles and reported increases of $20 \%$ 
and $30 \%$ for doses of 60 and $120 \mathrm{~kg} \mathrm{ha}^{-1}$ of $\mathrm{N}$, respectively, compared to the control. The inadequate management of a sugarcane field, especially with regards to $\mathrm{N}$ fertilization, can result in decreases in both crop productivity and longevity [34].

The SP of ratoon crops in response to the $\mathrm{Zn}$ doses was adjusted using the linear model, with $R^{2}>97 \%$ (Figure 3B). The SP increased by $10.10 \%, 10.10 \%, 9.90 \%$, and $7.90 \%$ when treated with $2.5 \mathrm{~kg} \mathrm{ha}^{-1}$ of $\mathrm{Zn}$ at N doses of $0,60,120$, and $180 \mathrm{~kg} \mathrm{ha}^{-1}$, respectively. Sugarcane SP also increased by 5.00, 5.30, 5.40, and $4.70 \mathrm{t} \mathrm{ha}^{-1}$ for each $1 \mathrm{~kg} \mathrm{ha}^{-1}$ increase in Zn at $\mathrm{N}$ doses 0, 60, 120, and $180 \mathrm{~kg} \mathrm{ha}^{-1}$, respectively (Figure 3B).

Nutrient availability in the soil is one of the major factors that limits the mean productivity of sugarcane [35-37]. Although fertilization is used to increase the soil nutrient availability, it can have a significant impact on the production costs of sugarcane, accounting for up to $25 \%$ of these costs.

The sugar yield of plant crops in response to the $\mathrm{N}$ doses was adjusted using the linear model, with $R^{2}>92 \%$ (Figure $4 \mathrm{~A}$ ). Compared with the control $\left(0 \mathrm{~kg} \mathrm{ha}^{-1}\right.$ of $\left.\mathrm{N}\right)$, the sugar yield increased by $12.00 \%, 14.90 \%, 15.80 \%, 14.70 \%$, and $14.30 \%$ when treated with $60 \mathrm{~kg} \mathrm{ha}^{-1}$ of $\mathrm{N}$ and increased by $36.10 \%, 44.70 \%, 47.60 \%, 43.90 \%$, and $42.80 \%$ when treated with $180 \mathrm{~kg} \mathrm{ha}^{-1}$ of $\mathrm{N}$, at the Zn doses of 0 , $2.5,5.0,7.5$, and $10.0 \mathrm{~kg} \mathrm{ha}^{-1}$, respectively. The sugar yield increased by $0.06 \mathrm{t} \mathrm{ha}^{-1}$ for each $1 \mathrm{~kg} \mathrm{ha}^{-1}$ increase in $\mathrm{N}$ at the $\mathrm{Zn}$ dose of $10 \mathrm{~kg} \mathrm{ha}^{-1}$ (Figure $4 \mathrm{~A}$ ). The maximum sugar yield $\left(>23 \mathrm{tha}^{-1}\right.$ ) was obtained in the fertigation treatment with $10 \mathrm{~kg} \mathrm{ha}^{-1}$ of $\mathrm{Zn}$ and $180 \mathrm{~kg} \mathrm{ha}^{-1}$ of N. Gouveia Neto [38] evaluated the sugar yield of sugarcane (plant crops) irrigated and fertilized with $130 \mathrm{~kg} \mathrm{ha}^{-1}$ and reported a mean sugar yield of $17.79 \mathrm{t} \mathrm{ha}^{-1}$.

(A)

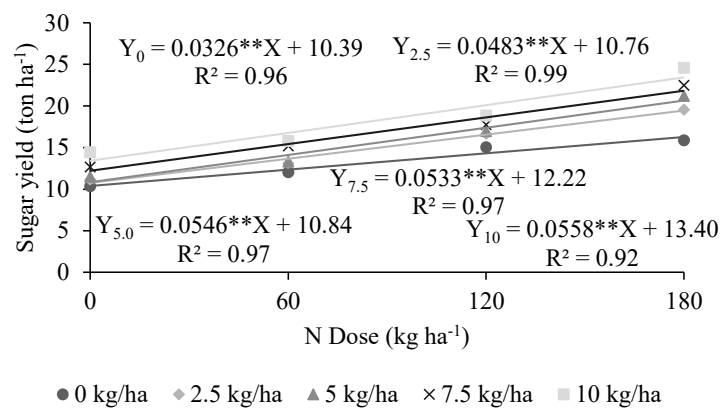

(B)

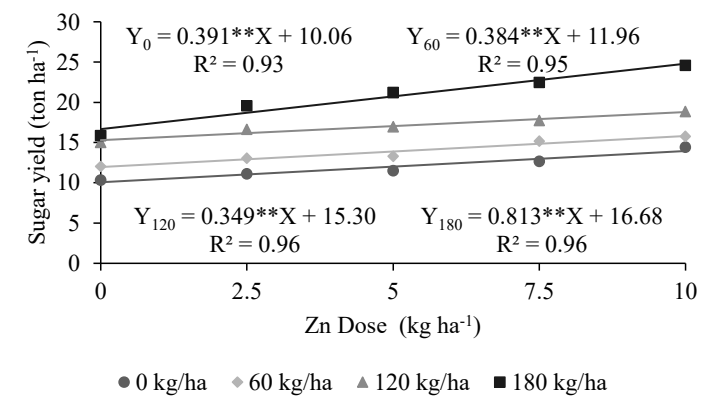

Figure 4. Sugar yield of sugarcane (plant crops) in response to nitrogen (A) and zinc (B) fertigation doses, under field conditions in Jataí, GO, Brazil. ${ }^{* *}$ significant at $p<0,01$ probability according to the $\mathrm{F}$ test. Doses of $\mathrm{Zn}, \mathrm{Y}_{0}: 0 \mathrm{~kg} \mathrm{ha}{ }^{-1}$ of $\mathrm{Zn}, \mathrm{Y}_{2.5}: 2.5 \mathrm{~kg} \mathrm{ha}^{-1}$ of $\mathrm{Zn}, \mathrm{Y}_{5.0}: 5.0 \mathrm{~kg} \mathrm{ha}^{-1}$ of $\mathrm{Zn}, \mathrm{Y}_{7.5}$ : $7.5 \mathrm{~kg} \mathrm{ha}^{-1}$ of $Z \mathrm{n}$ and $\mathrm{Y}_{10}: 10 \mathrm{~kg} \mathrm{ha}^{-1}$ of $\mathrm{Zn}(\mathbf{A})$. Doses of N, $Y_{0}: 0 \mathrm{~kg} \mathrm{ha}^{-1}$ of N, $Y_{60}: 60 \mathrm{~kg} \mathrm{ha}^{-1}$ of N, $\mathrm{Y}_{120}: 120 \mathrm{~kg} \mathrm{ha}^{-1}$ of N, $\mathrm{Y}_{180}: 180 \mathrm{~kg} \mathrm{ha}^{-1}$ of N (B).

Sugarcane crops fertigated with high doses of $\mathrm{N}$ usually presented significant increases in sugar productivity $\left(>22 \mathrm{t} \mathrm{ha}^{-1}\right)$, because sugarcane tends to show improved growth and development, which are normally associated with increases in the final values of alcohol and sugar production, in response to nutrient application via irrigation water [11,39].

The sugar yield of plant crops in response to the $\mathrm{Zn}$ doses was adjusted using the linear model, with $R^{2}>93 \%$ (Figure $4 \mathrm{~B}$ ). Compared with the control ( $0 \mathrm{~kg} \mathrm{ha}^{-1}$ of $\mathrm{Zn}$ ), the sugar yield increased by $7.00 \%, 6.10 \%, 4.60 \%$, and $8.20 \%$ when treated with $2.5 \mathrm{~kg} \mathrm{ha}^{-1}$ of $\mathrm{Zn}$ and increased by $28.00 \%, 24.30 \%$, $18.60 \%$, and $32.80 \%$ when treated with $10 \mathrm{~kg} \mathrm{ha}^{-1}$ of $\mathrm{Zn}$, at $\mathrm{N}$ doses of $0,60,120$, and $180 \mathrm{~kg} \mathrm{ha}^{-1}$, respectively. The sugar yield of sugarcane also increased by $0.39,0.38,0.35$, and $0.81 \mathrm{tha}^{-1}$ for each $1 \mathrm{~kg} \mathrm{ha}^{-1}$ of $\mathrm{Zn}$ increase at $\mathrm{N}$ doses of $0,60,120$, and $180 \mathrm{~kg} \mathrm{ha}^{-1}$, respectively (Figure 4B).

The sugar yield of ratoon crops in response to the $\mathrm{N}$ doses was adjusted using the linear model, with $R^{2}>84 \%$ (Figure $5 \mathrm{~A}$ ). Compared with the control $\left(0 \mathrm{~kg} \mathrm{ha}^{-1}\right.$ of $\left.\mathrm{N}\right)$, the sugar yield increased by $10.70 \%, 7.90 \%, 7.90 \%, 7.30 \%$, and $6.20 \%$ when treated with $60 \mathrm{~kg} \mathrm{ha}^{-1}$ of $\mathrm{N}$ and increased by $32.00 \%$, 
$23.60 \%, 23.70 \%, 21.80 \%$, and $18.70 \%$ when treated with $180 \mathrm{~kg} \mathrm{ha}^{-1}$ of $\mathrm{N}$, at the $\mathrm{Zn}$ doses of $0,2.5,5.0,7.5$, and $10.0 \mathrm{~kg} \mathrm{ha}^{-1}$, respectively. The sugar yield of sugarcane fertigated with $10 \mathrm{~kg} \mathrm{ha}^{-1}$ of $\mathrm{Zn}$ indicated an increase of $0.02 \mathrm{t} \mathrm{ha}^{-1}$ for each $1 \mathrm{~kg} \mathrm{ha}^{-1}$ increase in $\mathrm{N}$ at the $\mathrm{N}$ dose of $180 \mathrm{~kg} \mathrm{ha}^{-1}$ (Figure 5A).

(A)

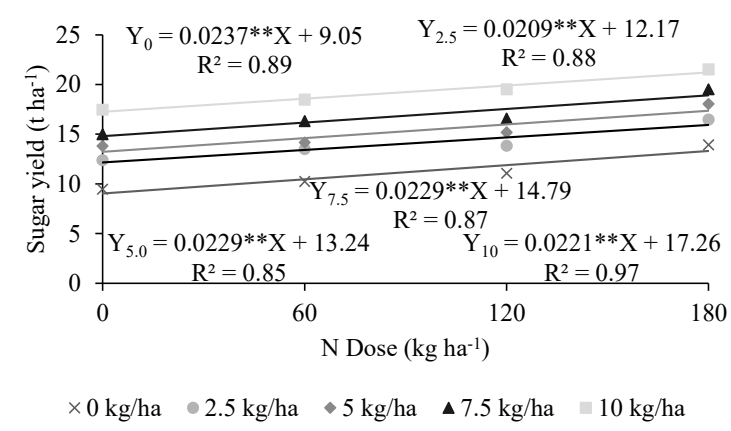

(B)

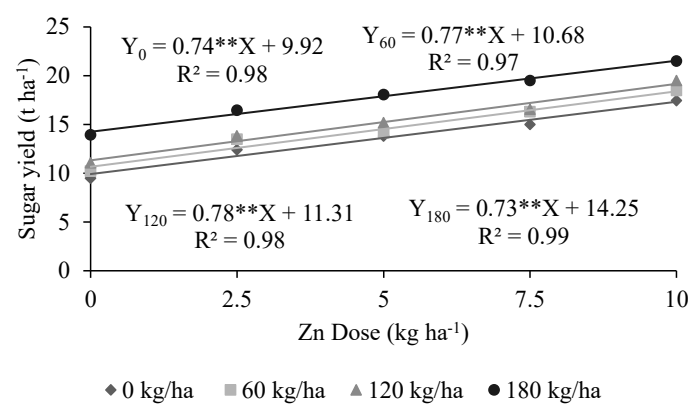

Figure 5. Sugar yield of sugarcane (ratoon crops) in response to nitrogen (A) and zinc (B) fertigation doses, under field conditions in Jataí, GO, Brazil. ** significant at $p<0,01$ probability according to the $F$ test. Doses of $Z n, Y_{0}: 0 \mathrm{~kg} \mathrm{ha}^{-1}$ of $Z n, Y_{2.5}: 2.5 \mathrm{~kg} \mathrm{ha}^{-1}$ of $Z \mathrm{n}, Y_{5.0}: 5.0 \mathrm{~kg} \mathrm{ha}^{-1}$ of $Z \mathrm{n}, Y_{7.5}$ : $7.5 \mathrm{~kg} \mathrm{ha}^{-1}$ of $Z \mathrm{n}$ and $Y_{10}: 10 \mathrm{~kg} \mathrm{ha}^{-1}$ of $Z \mathrm{n}(\mathrm{A})$. Doses of N, $\mathrm{Y}_{0}: 0 \mathrm{~kg} \mathrm{ha}^{-1}$ of N, $Y_{60}: 60 \mathrm{~kg} \mathrm{ha}^{-1}$ of N, $\mathrm{Y}_{120}: 120 \mathrm{~kg} \mathrm{ha}^{-1}$ of $\mathrm{N}, \mathrm{Y}_{180}: 180 \mathrm{~kg} \mathrm{ha}^{-1}$ of $\mathrm{N}(\mathbf{B})$.

Maschio [40] observed a gross sugar yield variation between 19.5 and $27.5 \mathrm{tha}^{-1}$ and lower raw sugar yields were reported for the varieties RB855453 (22.0 $\left.\mathrm{t} \mathrm{ha}^{-1}\right)$, CTC8 (21.6 tha $\left.{ }^{-1}\right)$, CTC14 (20.4 tha $\left.{ }^{-1}\right)$, and SP81-3 $250\left(19.5 \mathrm{t} \mathrm{ha}^{-1}\right)$.

The sugar yield of ratoon crops in response to the $\mathrm{Zn}$ doses was adjusted using the linear model, with $R^{2}>97 \%$ (Figure $5 \mathrm{~B}$ ). The sugar yield increased by $10.70 \%, 10.50 \%, 10.20 \%$, and $8.50 \%$ when treated with $2.5 \mathrm{~kg} \mathrm{ha}^{-1}$ of $\mathrm{Zn}$ at $\mathrm{N}$ doses of $0,60,120$, and $180 \mathrm{~kg} \mathrm{ha}^{-1}$, respectively. The sugar yield of sugarcane also increased by $0.74,0.77,0.78$, and $0.73 \mathrm{tha}^{-1}$ for each $1 \mathrm{~kg} \mathrm{ha}^{-1}$ increase in $\mathrm{Zn}$ at $\mathrm{N}$ doses of $0,60,120$, and $180 \mathrm{~kg} \mathrm{ha}^{-1}$, respectively (Figure 5B).

The alcohol yield of plant crops in response to the $\mathrm{N}$ doses was adjusted using the linear model, with $R^{2}>92 \%$ (Figure 6A). Compared with the control $\left(0 \mathrm{~kg} \mathrm{ha}^{-1}\right.$ of $\left.\mathrm{N}\right)$, the alcohol yield increased by $11.90 \%, 14.80 \%, 15.80 \%, 14.60 \%$, and $14.20 \%$ when treated with $60 \mathrm{~kg} \mathrm{ha}^{-1}$ of $\mathrm{N}$ and increased by $35.86 \%, 44.53 \%, 47.49 \%, 43.86 \%$, and $42.67 \%$ when treated with $180 \mathrm{~kg} \mathrm{ha}^{-1}$ of N, at the $\mathrm{Zn}$ doses of 0 , $2.5,5.0,7.5$, and $10.0 \mathrm{~kg} \mathrm{ha}^{-1}$, respectively. The alcohol yield of sugarcane increased by $0.04 \mathrm{~m}^{3} \mathrm{ha}^{-1}$ for each $1 \mathrm{~kg} \mathrm{ha}^{-1}$ increase in $\mathrm{N}$ at the $\mathrm{Zn}$ dose of $10 \mathrm{~kg} \mathrm{ha}^{-1}$ (Figure 6A).

(A)

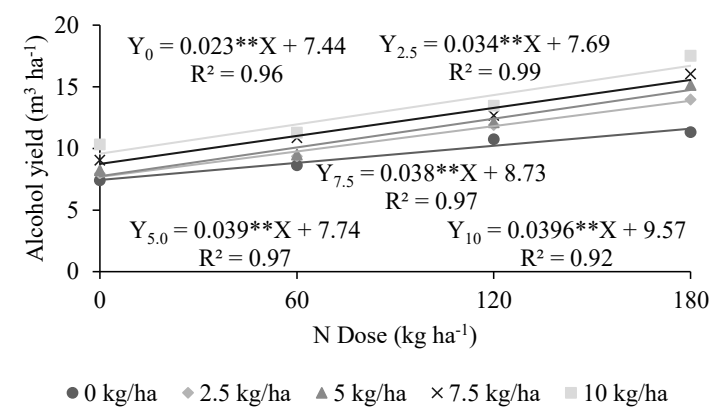

(B)

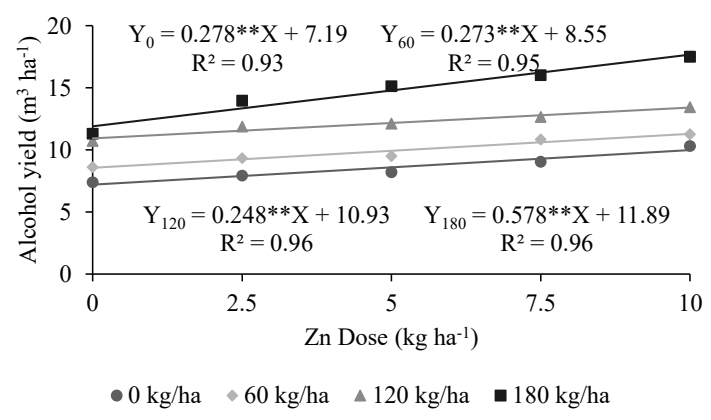

Figure 6. Alcohol yield of sugarcane (plant crops) in response to nitrogen (A) and zinc (B) fertigation doses, under field conditions in Jataí, GO, Brazil. ${ }^{* *}$ significant at $p<0,01$ probability according to the $\mathrm{F}$ test. Doses of $\mathrm{Zn}, \mathrm{Y}_{0}: 0 \mathrm{~kg} \mathrm{ha}{ }^{-1}$ of $\mathrm{Zn}, \mathrm{Y}_{2.5}: 2.5 \mathrm{~kg} \mathrm{ha}^{-1}$ of $\mathrm{Zn}, \mathrm{Y}_{5.0}: 5.0 \mathrm{~kg} \mathrm{ha}^{-1}$ of $\mathrm{Zn}, \mathrm{Y}_{7.5}$ : $7.5 \mathrm{~kg} \mathrm{ha}^{-1}$ of $Z \mathrm{n}$ and $\mathrm{Y}_{10}: 10 \mathrm{~kg} \mathrm{ha}^{-1}$ of $\mathrm{Zn}(\mathbf{A})$. Doses of N, $\mathrm{Y}_{0}: 0 \mathrm{~kg} \mathrm{ha}^{-1}$ of N, $\mathrm{Y}_{60}: 60 \mathrm{~kg} \mathrm{ha}^{-1}$ of N, $\mathrm{Y}_{120}: 120 \mathrm{~kg} \mathrm{ha}^{-1}$ of $\mathrm{N}, \mathrm{Y}_{180}: 180 \mathrm{~kg} \mathrm{ha}^{-1}$ of $\mathrm{N}(\mathbf{B})$. 
The maximum alcohol yield ( $>15 \mathrm{~m}^{3} \mathrm{ha}^{-1}$ ) was found in sugarcane fertigated with $10 \mathrm{~kg} \mathrm{ha}^{-1}$ of $\mathrm{Zn}$ and $180 \mathrm{~kg} \mathrm{ha}^{-1}$ of $\mathrm{N}$. Alcohol yields $12 \mathrm{~m}^{3} \mathrm{ha}^{-1}$ have been observed in sugarcane irrigated and fertilized with $\mathrm{N}$ doses $>100 \mathrm{~kg} \mathrm{~m}^{3} \mathrm{ha}^{-1}[39,41]$.

The alcohol yield of plant crops in response to the $\mathrm{Zn}$ doses was adjusted using the linear model, with $R^{2}>93 \%$ (Figure 6B). Compared with the control $\left(0 \mathrm{~kg} \mathrm{ha}^{-1}\right.$ of $\left.\mathrm{Zn}\right)$, the alcohol yield increased by $6.96 \%, 6.00 \%, 4.60 \%$, and $8.17 \%$ when treated with $2.5 \mathrm{~kg} \mathrm{~m}^{3} \mathrm{ha}^{-1}$ of $\mathrm{Zn}$ and increased by $27.80 \%, 24.20 \%$, $18.50 \%$, and $32.70 \%$ when treated with $10 \mathrm{~kg} \mathrm{ha}^{-1}$ of $\mathrm{Zn}$, at $\mathrm{N}$ doses of $0,60,120$, and $180 \mathrm{~kg} \mathrm{~m}^{3} \mathrm{ha}^{-1}$, respectively. The alcohol yield also increased by $0.28,0.27,0.25$, and $0.58 \mathrm{~m}^{3} \mathrm{ha}^{-1}$ for each $1 \mathrm{~kg} \mathrm{ha}^{-1}$ increase in $\mathrm{Zn}$ at $\mathrm{N}$ doses of $0,60,120$, and $180 \mathrm{~kg} \mathrm{ha}^{-1}$, respectively (Figure 6B).

Chandiposha et al. [42] reported increases in plant height, stem diameter, productivity, and sugar and alcohol yields in sugarcane due to the additional availability of $\mathrm{N}$ and $\mathrm{Zn}$. Increased $\mathrm{N}$ and $\mathrm{Zn}$ doses have been shown to increase the accumulation of stalk dry matter, total aerial dry matter, and the number and length of internodes; thus improving the growth of plants and resulting in higher sugar and alcohol yields [11,41,43].

The alcohol yield of ratoon crops in response to the $\mathrm{N}$ doses was adjusted using the linear model, with $R^{2}>84.8 \%$ (Figure $7 \mathrm{~A}$ ). Compared with the control $\left(0 \mathrm{~kg} \mathrm{ha}^{-1}\right.$ of $\left.\mathrm{N}\right)$, the alcohol yield increased by $10.57 \%, 7.82 \%, 7.89 \%, 7.21 \%$, and $6.10 \%$ when treated with $60 \mathrm{~kg} \mathrm{ha}^{-1}$ of $\mathrm{N}$ and increased by $31.70 \%$, $23.40 \%, 23.70 \%, 21.60 \%$, and $18.40 \%$ when treated with $180 \mathrm{~kg} \mathrm{ha}^{-1}$ of $\mathrm{N}$, at the $\mathrm{Zn}$ doses of $0,2.5,5.0,7.5$, and $10.0 \mathrm{~kg} \mathrm{ha}^{-1}$, respectively. The alcohol yield of sugarcane fertigated with $10 \mathrm{~kg} \mathrm{ha}^{-1}$ of $\mathrm{Zn}$ indicated an increase of $0.01 \mathrm{~m}^{3} \mathrm{ha}^{-1}$ for each $1 \mathrm{~kg} \mathrm{ha}^{-1}$ increase in $\mathrm{N}$ at the $\mathrm{N}$ dose of $180 \mathrm{~kg} \mathrm{ha}^{-1}$ (Figure 7A).

(A)

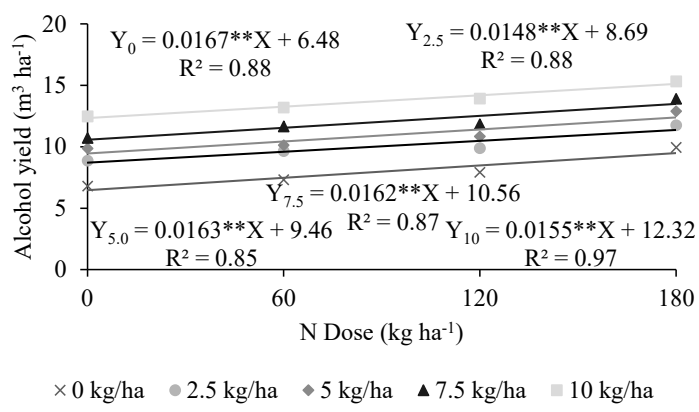

(B)

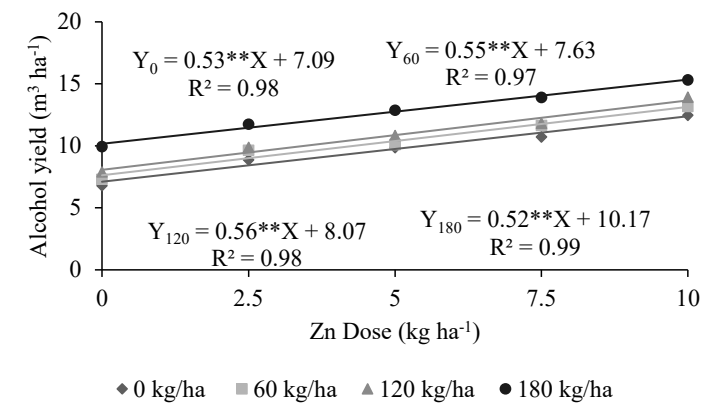

Figure 7. Alcohol yield of sugarcane (ratoon crops) in response to nitrogen (A) and zinc (B) fertigation doses, under field conditions in Jataí, GO, Brazil. ${ }^{* *}$ significant at $p<0,01$ probability according to the $\mathrm{F}$ test. Doses of $\mathrm{Zn}, \mathrm{Y}_{0}: 0 \mathrm{~kg} \mathrm{ha}{ }^{-1}$ of $\mathrm{Zn}, \mathrm{Y}_{2.5}: 2.5 \mathrm{~kg} \mathrm{ha}^{-1}$ of $\mathrm{Zn}, \mathrm{Y}_{5.0}: 5.0 \mathrm{~kg} \mathrm{ha}^{-1}$ of $\mathrm{Zn}, \mathrm{Y}_{7.5}$ : $7.5 \mathrm{~kg} \mathrm{ha}^{-1}$ of $Z \mathrm{n}$ and $\mathrm{Y}_{10}: 10 \mathrm{~kg} \mathrm{ha}^{-1}$ of $Z \mathrm{n}(\mathrm{A})$. Doses of N, $\mathrm{Y}_{0}: 0 \mathrm{~kg} \mathrm{ha}^{-1}$ of N, $\mathrm{Y}_{60}: 60 \mathrm{~kg} \mathrm{ha}^{-1}$ of N, $\mathrm{Y}_{120}: 120 \mathrm{~kg} \mathrm{ha}^{-1}$ of $\mathrm{N}, \mathrm{Y}_{180}: 180 \mathrm{~kg} \mathrm{ha}^{-1}$ of $\mathrm{N}(\mathbf{B})$.

Carvalho et al. [44] reported increases in the gross yield of alcohol and SP in response to an increased irrigation level. Other studies also reported increased growth, productivity, technological quality, and gross yields of alcohol and sugar in sugarcane fertigated with $\mathrm{N}$ [41,45-47].

The alcohol yield of ratoon crops in response to the $\mathrm{Zn}$ doses was adjusted using the linear model, with $R^{2}>97 \%$ (Figure 7B). The alcohol yield increased by $10.67 \%, 10.48 \%, 10.23 \%$, and $8.43 \%$ when treated with $2.5 \mathrm{~kg} \mathrm{ha}^{-1}$ of $\mathrm{Zn}$ at $\mathrm{N}$ doses of $0,60,120$, and $180 \mathrm{~kg} \mathrm{ha}^{-1}$, respectively. The alcohol yield of sugarcane also increased by $0.53,0.55,0.56$, and $0.52 \mathrm{~m}^{3} \mathrm{ha}^{-1}$ for each $1 \mathrm{~kg} \mathrm{ha}^{-1}$ increase in $\mathrm{Zn}$ at N doses of 0, 60, 120, and $180 \mathrm{~kg} \mathrm{ha}^{-1}$, respectively (Figure 7B).

Azevedo [48] researched plant cane and reported a maximum gross alcohol yield of $11.50 \mathrm{~m}^{3} \mathrm{ha}^{-1}$ with a total quantity of water of $1043 \mathrm{~mm}$. Cunha et al. [41] reported that the gross alcohol yield increased by $0.03 \mathrm{~m}^{3} \mathrm{ha}^{-1}$ for each $1 \%$ increase in water replacement in sugarcane. 


\section{Conclusions}

The sugar and alcohol yield of sugarcane (plant crops) in relation to zinc doses is potentiated with the use of $180 \mathrm{~kg} \mathrm{ha}^{-1}$ nitrogen fertigation, in which the increments are significant $\left(0.81 \mathrm{ton} \mathrm{ha}^{-1}\right.$ and $\left.0.58 \mathrm{~m}^{3} \mathrm{ha}^{-1}\right)$ for each $1 \mathrm{~kg} \mathrm{ha}^{-1}$ increase in $\mathrm{Zn}$, in the other doses $\left(0,60,120 \mathrm{~kg} \mathrm{ha}^{-1}\right.$ of N), these increases practically do not vary ( 0.37 ton ha ${ }^{-1}$ and $\left.0.27 \mathrm{~m}^{3} \mathrm{ha}^{-1}\right)$.

Compared with the control (without $\mathrm{N}$ fertigation), the sugarcane productivity (plant and ratoon crops) increased by $38.90 \%$ and $13.70 \%$ when treated with $180 \mathrm{~kg} \mathrm{ha}^{-1}$ of $\mathrm{N}$ at the $\mathrm{Zn}$ dose of $10 \mathrm{~kg} \mathrm{ha}^{-1}$.

Compared with the control (without Zn fertigation), the sugarcane productivity (plant and ratoon crops) increased by $30.80 \%$ and $31.83 \%$ when treated with the maximum dose of zinc and $\mathrm{N}$, respectively; the increase in sugarcane productivity is the same in plant and ratoon crops that shows the benefit of $\mathrm{Zn}$ fertigation.

The sugar and alcohol yields of sugarcane (variety IACSP 95-5000) were improved with the fertigation of $180 \mathrm{~kg} \mathrm{ha}^{-1}$ of $\mathrm{N}$, in relation to $\mathrm{Zn}$ doses. The recommended $\mathrm{Zn}$ dose for irrigated sugarcane or with high doses of $\mathrm{N}$ fertilization is $10 \mathrm{~kg} \mathrm{ha}^{-1}$.

The recommendation of highest doses of zinc and nitrogen in sugarcane (plant and ratoon crops) had the greatest effects on the productive potential of the crop, providing better sugar and alcohol yields. Sugarcane (variety IACSP 95-5000) has the productive performance, sugar and alcohol yield, optimized and maximized when fertigated with $10 \mathrm{~kg} \mathrm{ha}^{-1}$ of zinc and $180 \mathrm{~kg} \mathrm{ha}^{-1}$ of nitrogen.

Author Contributions: The authors F.N.C., M.B.T., E.C.d.S., N.F.d.S., C.T.S.C., V.M.V., W.A.M., L.N.S.d.S., F.R.C.F., D.K.M.A., J.A.B.S. and L.F.G. have contributed equally to the research design, development, and the writing of the manuscript. All authors have read and agreed to the published version of the manuscript.

Funding: This research was funded by National Council for Scientific and Technological Development-CNPq grant number 305218, Ministry of Science, Technology, Innovation, and Communications-MCTIC grant number 446999, the Coordination for the Improvement for Higher Level Personnel-CAPES, the Research Support Foundation of the State of Goiás-FAPEG and the APC was funded by Federal Institute of Education, Science, and Technology Goiano (IFGoiano) - Campus Rio Verde.

Acknowledgments: The authors thank the National Council for Scientific and Technological Development (CNPq); the Coordination for the Improvement for Higher Level Personnel (CAPES); the Research Support Foundation of the State of Goiás (FAPEG); the Ministry of Science, Technology, Innovation, and Communications (MCTIC); the Raízen Plant Jataí unit; and the Federal Institute of Education, Science, and Technology Goiano (IFGoiano) Campus Rio Verde, for the financial and structural support to conduct this study.

Conflicts of Interest: The authors declare no conflict of interest.

\section{References}

1. Costa, M.C.G. Eficiência Agronômica de Fontes Nitrogenadas na Cultura da Cana-de-Açúcar em Sistema de Colheita sem Despalha a Fogo. Master's Thesis, Escola Superior de Agricultura "Luiz de Queiróz", Piracicaba, Brazil, 2001; p. 79.

2. Regis, J.A.V.B. Adaptabilidade e Estabilidade Fenotípica de Clones de Cana-de-Açúcar em Dois Ciclos Produtivos. Master's Thesis, Universidade Estadual Paulista, Júlio de Mesquita Filho, UNESP, Ilha Solteira, Brazil, 2016; p. 56.

3. Inman, B.N.G. Sugarcane water stress criteria for irrigation and drying off. Field Crops Res. 2004, 89, 107-122. [CrossRef]

4. Dantas Neto, J.; Figueredo, J.L.C.; Farias, C.H.A.; Azevedo, H.M.; Azevedo, C.A.V. Resposta da cana -de -açúcar, primeira soca, a níveis de irrigação e adubação de cobertura. Rev. Bras. Eng. Agrícola Ambient. 2006, 10, 283-288. [CrossRef]

5. Salassier, B. Manejo da Irrigação na Cana-de-Açúcar. Available online: http://www.agencia.cnptia.embrapa. br/Repositorio/Cana_irrigada_producao_000fi (accessed on 20 February 2020).

6. Dalri, A.B.; Cruz, R.L. Produtividade da cana-de-açúcar fertirrigada com N e K via gotejamento subsuperficial. Irrig. Botucatu 2008, 28, 516-524. [CrossRef]

7. Mussi, R.F.; Alves Junio, J.; Evangelista, A.W.P.; Casaroli, D.; Flores, R.A. Produção de cana-de-açúcar irrigada e fertirrigada com efluente urbano de Goiânia-GO. Rev. Agrotecnologia Ipameri 2017, 8, 46-54. [CrossRef] 
8. Dalri, A.B.; Cruz, R.L. Efeito da frequência de irrigação subsuperficial por gotejamento no desenvolvimento da cana-de-açúcar (Saccharum spp.). Irrig. Botucatu 2002, 7, 29-34. [CrossRef]

9. Moura, M.V.P.S.; Farias, C.H.A.; Azevedo, C.A.V.; Pontes Neto, J.; De Azevedo, H.M.; Pordeus, R.V. Doses de adubação nitrogenada e potássica em cobertura na cultura da cana-de-açúcar, primeira soca, com e sem irrigação. Ciência Agrotécnica 2005, 29, 753-760. [CrossRef]

10. Roberts, T.L. Improving nutrients use efficiency. Turk. J. Agric. For. 2008, 32, 177-182.

11. Da Silva, N.F.; Cunha, F.N.; De Oliveira, R.C.; Moura, L.M.D.F.; De Moura, L.C.; Teixeira, M.B.; Bastos, F.J.D.C. Crescimento da cana-de-açúcar sob aplicação de nitrogênio via gotejamento subsuperficial. Rev. Bras. Agric. Irrig. 2014, 8, 1-11. [CrossRef]

12. Rhein, A.F.L. Produtividade e Qualidade da Cana-de-Açúcar Sob Doses de Nitrogênio Via Fertirrigação Subsuperficial por Gotejamento. Ph.D. Thesis, Faculdade de Ciências Agronômicas, Universidade Estadual Paulista, Botucatu, Brazil, 2012; p. 117.

13. Anderson, D.L.; Bowen, J.E. Nutrição da Cana de Açúcar; POTAFOS: Piracicaba, São Paulo, Brazil, $1992 ;$ p. 40.

14. Farias, C.H.A. Otimização do Uso da Água e do Zinco na Cana-de-Açúcar em Tabuleiro Costeiro Paraibano. Universidade Federal de Campina Grande; Centro de Tecnologia e Recursos Naturais: Campina Grande, Brazil, 2006; p. 142.

15. Cunha, F.N. Crescimento e Rendimento da Cana-de-Açúcar Submetida a Diferentes Níveis de Água por Gotejamento. Master's Thesis, Instituto Federal Goiano, Goiânia, Brazil, 2014; p. 76.

16. Mellis, E.V.; Quaggio, J.A.; Teixeira, L.A.J. Boletim Zinco: Cana-de-Açúcar. Iniciativa Nutriente Zinco (ZNI); IAC: Campinas, São Paulo, Brasil, 2014; pp. 1-6.

17. Köppen, W. Köppen Climate Classification. Geography about. Available online: http://geography.about. com/library/weekly/aa011700b.htm (accessed on 2 February 2020).

18. Santos, H.G.; Jacomine, P.K.T.; Anjos, L.H.C.; Oliveira, V.Á.; Oliveira, J.B.; Coelho, M.R.; Lumbreras, J.F.; Cunha, T.J.F. Sistema Brasileiro de Classificação de Solo. Empresa Brasileira de Pesquisa Agropecuária, 3rd ed.; Centro Nacional de Pesquisa de Solos: Rio de Janeiro, Brazil, 2013; p. 353.

19. Sousa, D.M.G.; Lobato, E. Cerrado: Correção do Solo e Adubação, 2nd ed.; Embrapa Informação Tecnológica/ Embrapa-CPA: Brasília, Brazil, 2004; p. 416.

20. Chaves, V.A.; Dos Santos, S.G.; Schultz, N.; Pereira, W.; Sousa, J.S.; Monteiro, R.C.; Reis, V.M. Desenvolvimento Inicial de Duas Variedades de Cana-de-açúcar Inoculadas com Bactérias Diazotróficas. Rev. Bras. Ciência Solo 2015, 39, 1595-1602. [CrossRef]

21. Rossetto, R. Maturação da Cana-de-Açúcar. Available online: http://www.agencia.cnptia.embrapa.br/gestor/ cana-de-acucar/arvore/CONTAG01_90_22122006154841.html (accessed on 10 January 2020).

22. CONSECANA. Manual de Instruções. Conselho dos Produtores de Cana-de-Açúcar, Açúcar, Álcool do Estado de São Paulo, 5th ed.; CONSECANA: Piracicaba, Brazil, 2006; p. 112.

23. Caldas, C. Manual de Análises Selecionadas Para Indústrias Sucroalcooleiras; Sindicato da Indústria e do Álcool do Estado de Alagoas: Maceió, Brazil, 1998; p. 424.

24. Ferreira, D.F. Sisvar: A computer statistical analysis system. Ciência Agrotecnologia 2011, 35, $1039-1042$. [CrossRef]

25. Teodoro, I.; Dantas Neto, J.; Souza, J.L.; Lyra, G.B.; Brito, K.S.; Sá, L.A.; Santos, M.A.L.; Sarmento, P.L.V.S. Isoquantas de produtividade da cana-de-açúcar em função de níveis de irrigação e adubação nitrogenada. Irrig. Botucatu 2013, 18, 387-401. [CrossRef]

26. Joris, H.A.W. Nitrogênio na Produção de Cana-de-Açúcar: Aspectos Agronômicos e Ambientais. Ph.D. Thesis, Instituto Agronômico, IAC, Campinas, Brazil, 2015; p. 134.

27. Franco, H.C.J.; Otto, R.; Vitti, A.C.; Faroni, C.E.; Oliveira, E.C.A.; Fortes, C.; Ferreira, D.A.; Kölln, O.T.; Garside, A.L.; Trivelin, P.C.O. Residual recovery and yield performance of nitrogen fertilizer applied at sugarcane planting. Sci. Agric. 2015, 72, 528-534. [CrossRef]

28. Leal, D.P.V. Evapotranspiração da Cana-de-Açúcar e Fotossíntese Acumulada em Biomassa e energia, Para Diferentes Variedades, Disponibilidades Hídricas no Solo e Ciclos de Cultivos. Master's Thesis, Escola Superior de Agricultura Luiz de Queiroz, Universidade de São Paulo, Piracicaba, Brazil, 2012.

29. Sousa, S.F.G.; Marasca, I.; Paludo, V.; Silva, P.R.A.; Lanças, K.P. Produtividade da cultura de cana de açúcar com e sem a aplicação de fósforo em profundidade utilizando equipamento de preparo profundo mecanizado. Energ. Agric. Botucatu 2015, 30, 258-263. 
30. Tasso Junior, L.C.; Marques, M.O.; Camilotti, F.; Silva, T. Extração de macronutrientes em cinco variedades de cana-de-açúcar cultivadas na região centro-norte do estado de São Paulo. In Açúcar, Álcool e Subprodutos; STAB: Piracicaba, Brazil, 2007; Volume 25, pp. 6-8.

31. Udayakumar, S.; Baskar, K.; Saliha, B.B. Impact of fertilisation on yield and quality of ratoon sugarcane in theni district (India). J. Int. Acad. Res. Multidiscip. 2014, 2, 9.

32. Becari, G.R.G. Resposta da Cana-Planta à Aplicação de Micronutrientes. Ph.D. Thesis, Instituto Agronômico IAC, Campinas, Brazil, 2010; p. 79.

33. Orlando Filho, J.; Rodella, A.A.; Beltrame, J.A.; Lavorenti, N.A. Doses, fontes e formas de aplicação de nitrogênio em cana-de-açúcar. STAB 1999, 17, 39-41.

34. Vitti, A.C.; Trivelin, P.C.O.; Gava, G.J.C.; Penatti, C.P.; Bologna, I.R.; Faroni, C.E.; Franco, H.C.J. Produtividade da cana-de-açúcar relacionada ao nitrogênio residual da adubação e do sistema radicular. Pesqui. Agropecuária Bras. 2007, 42, 249-256. [CrossRef]

35. Trivelin, P.C.O. Utilização do Nitrogênio pela Cana-de-Açúcar: Três Casos Estudados com o Uso do Traçador 15N. Ph.D. Thesis, Escola Superior de Agricultura Luiz de Queiroz, Universidade de São Paulo, Piracicaba, Brazil, 2000; 143p.

36. Marafon, A.C.; Endres, L. Adubação Silicatada em Cana-de-Açúcar. Aracaju: Embrapa Tabuleiros Costeiros. Available online: http://www.infoteca.cnptia.embrapa.br/handle/doc/914935 (accessed on 21 January 2020).

37. Esperancini, M.S.T.; Afonso, P.F.N.; Gava, G.J.C.; Villas Boas, R.L. Dose ótima econômica de nitrogênio em cana-de-açúcar aplicada via fertirrigação por gotejamento. Irriga 2015, 1, 28-39. [CrossRef]

38. Gouveia, N.C.G. Rendimento Agroindustrial da Cana-de-Açúcar sob Suplementação Hídrica e Parcelamento de Nitrogênio. Ph.D. Thesis, Universidade Federal de Campina Grande, Campina Grande, Brazil, 2012; p. 145.

39. Júnior, A.S.D.A.; Bastos, E.A.; Ribeiro, V.Q.; Duarte, J.A.L.; Braga, D.L.; Noleto, D.H. Níveis de água, nitrogênio e potássio por gotejamento subsuperficial em cana-de-açúcar. Pesqui. Agropecuária Bras. 2012, 47, 76-84. [CrossRef]

40. Maschio, R. Produtividade da Água em Biomassa e Energia para 24 Variedades de Cana-de-Açúcar; Escola Superior de Agricultura, Luiz de Queiroz: Piracicaba, Brazil, 2011; p. 87.

41. Cunha, F.N.; Silva, N.F.; Sousa, A.E.C.; Teixeira, M.B.; Soares, F.A.L.; Vidal, V.M. Yield of sugarcane submitted to nitrogen fertilization and water depths by subsurface drip irrigation. Rev. Bras. Eng. Agr. Amb. 2016, 20, 841-846. [CrossRef]

42. Chandiposha, M.; Kunedzimwe, N.; Munyaradzi, G.; Chiriman'ombe, D. Comparisons of sugar blend 1 plus fertilizer over straight fertilizer as basal application on growth and yield of sugarcane (Saccharum officinarum L.). Int. J. Agron. Agric. Res. 2014, 4, 89-93.

43. Alloway, B.J. Zinc in Soils and Crop Nutrition; International Zinc Association (IZA): Brussels, Belgium, $2004 ;$ p. 116.

44. De Carvalho, C.M.; De Azevedo, H.M.; Neto, J.D.; Farias, C.H.D.A.; Silva, C.T.S.; Filho, R.R.G. Rendimento de açúcar e álcool da cana-de-açúcar submetida a diferentes níveis de irrigação. Rev. Bras. Ciências Agrárias 2009, 4, 72-77. [CrossRef]

45. Sanchez-Roman, R.M.; Silva, N.F.; Cunha, F.N.; Teixeira, M.B.; Soares, F.A.L.; Ribeiro, P.H.P. Produtividade da cana-de-açúcar submetida a diferentes reposições hídricas e nitrogênio em dois ciclos. Irriga 2015, 1, 198-210. [CrossRef]

46. Da Silva, N.F.; De Moura, L.C.; Cunha, F.N.; Ribeiro, P.H.; Carvalho, J.J.; Teixeira, M.B. Qualidade industrial da cana-de-açúcar fertirrigada sob diferentes lâminas de água no sudoeste goiano. Rev. Bras. Agric. Irrig. 2014, 8, 280-295. [CrossRef]

47. Da Silva, N.F.; Cunha, F.N.; Teixeira, M.B.; Soares, F.A.L. Crescimento vegetativo da cana-de-açúcar submetida a lâminas de irrigação e fertirrigação nitrogenada via gotejamento subsuperficial. Rev. Bras. Agric. Irrig. 2015, 9, 79-90. [CrossRef]

48. Azevedo, H.M. Resposta da Cana-de-Açúcar a Níveis de Irrigação e de Adubação de Cobertura Nos Tabuleiros da Paraíba. Ph.D. Thesis, UFCG, Campina Grande, Brazil, 2002; p. 112.

(C) 2020 by the authors. Licensee MDPI, Basel, Switzerland. This article is an open access article distributed under the terms and conditions of the Creative Commons Attribution (CC BY) license (http://creativecommons.org/licenses/by/4.0/). 